\title{
Evidence of adaptation, niche separation and microevolution within the genus Polaromonas on Arctic and Antarctic glacial surfaces
}

\author{
Jan Gawor ${ }^{1} \cdot$ Jakub Grzesiak $^{2} \cdot$ Joanna Sasin-Kurowska $^{3} \cdot$ Piotr Borsuk $^{3}$. \\ Robert Gromadka ${ }^{1}$ - Dorota Górniak ${ }^{4} \cdot$ Aleksander Świątecki $^{4}$. \\ Tamara Aleksandrzak-Piekarczyk ${ }^{5}$ - Marek K. Zdanowski ${ }^{2}$
}

Received: 24 February 2016 / Accepted: 5 April 2016 / Published online: 20 April 2016

(C) The Author(s) 2016. This article is published with open access at Springerlink.com

\begin{abstract}
Polaromonas is one of the most abundant genera found on glacier surfaces, yet its ecology remains poorly described. Investigations made to date point towards a uniform distribution of Polaromonas phylotypes across the globe. We compared 43 Polaromonas isolates obtained from surfaces of Arctic and Antarctic glaciers to address this issue. 16S rRNA gene sequences, intergenic transcribed spacers (ITS) and metabolic fingerprinting showed great differences between hemispheres but also between neighboring glaciers. Phylogenetic distance between Arctic and Antarctic isolates indicated separate species. The Arctic group clustered similarly, when constructing
\end{abstract}

Communicated by A. Oren.

Electronic supplementary material The online version of this article (doi:10.1007/s00792-016-0831-0) contains supplementary material, which is available to authorized users.

Jakub Grzesiak

jgrzesiak@arctowski.pl

1 Laboratory of DNA Sequencing and Oligonucleotide Synthesis, Institute of Biochemistry and Biophysics, Polish Academy of Sciences, Pawińskiego 5a, 02-106 Warsaw, Poland

2 Department of Antarctic Biology, Institute of Biochemistry and Biophysics, Polish Academy of Sciences, Pawińskiego 5a, 02-106 Warsaw, Poland

3 Institute of Genetics and Biotechnology, Faculty of Biology, Warsaw University, Pawińskiego 5a, 02-106 Warsaw, Poland

4 Department of Microbiology, Faculty of Biology and Biotechnology, University of Warmia and Mazury, Oczapowskiego 1A, 10-719 Olsztyn, Poland

5 Department of Microbial Biochemistry, Institute of Biochemistry and Biophysics, Polish Academy of Sciences, Pawińskiego 5a, 02-106 Warsaw, Poland dendrograms based on 16S rRNA gene and ITS sequences, as well as metabolic traits. The Antarctic strains, although almost identical considering 16S rRNA genes, diverged into 2 groups based on the ITS sequences and metabolic traits, suggesting recent niche separation. Certain phenotypic traits pointed towards cell adaptation to specific conditions on a particular glacier, like varying $\mathrm{pH}$ levels. Collected data suggest, that seeding of glacial surfaces with Polaromonas cells transported by various means, is of greater efficiency on local than global scales. Selection mechanisms present of glacial surfaces reduce the deposited Polaromonas diversity, causing subsequent adaptation to prevailing environmental conditions. Furthermore, interactions with other supraglacial microbiota, like algae cells may drive postselectional niche separation and microevolution within the Polaromonas genus.

Keywords Polaromonas - 16S rRNA gene - ITS . Glacier $\cdot$ Bacteria $\cdot$ Biogeography

\section{Introduction}

Biogeography has always been a topic of major interest for the scientific community (Hubbell 2001). It was mainly focused on spatial distribution of multicellular organisms, neglecting the microbiome, including prokaryotes (Nemergut et al. 2011; Ramette and Tiedje 2007). This was mainly due to the tremendous dispersal potential of microbes, and only environmental selection determining which species were abundant (Martiny et al. 2006). Indeed at the genus level, many prokaryotes have a cosmopolitan distribution in the environment at local, regional, and continental scales (Rodrigues et al. 2009). However, further investigations of genetic, phenotypic and physiological microbial features 
revealed profound differences between isolates obtained from geographically distant areas, showing that endemism was more common than previously thought. These findings best fitted well-isolated extreme habitats, where the inhospitable outside environment hindered the dispersal of highly specialized microbes, leading to geographic isolation and subsequent neutral divergence (Ramette and Tiedje 2007).

In many ways, glaciers may be seen as island-like habitats. Those extreme ecosystems are featured on every continent and separated by large expanses of temperate terrestrial and marine areas (Shiklomanov 1993; Paterson 1994). Although not entirely isolated, (connected to some extent through the upper atmosphere via the movement of cold air masses) they are an environment where profound selective forces are at work (Hodson et al. 2008).

The bacterial genus Polaromonas seems to be among the dominant bacterial taxa in glacial ice since closely aligned sequences were discovered by metagenomic studies of glacial habitats worldwide, making Polaromonas one of the model taxons for investigating microbial distribution patterns in the terrestrial cryosphere (Willems 2014).

Papers regarding this topic were published previously (Darcy et al. 2011), using culture independent approach based on 16S rRNA gene sequences. Employment of large data sets to investigate genetic dispersal of Polaromonas phylotypes across global scales has led to the conclusion of a very weak genetic isolation between glacier habitats.

As much as environmental small subunit ribosomal gene analysis has advanced our understanding of microbial communities, it has its limitations due to persistence of extracellular DNA released into environment (Nielsen et al. 2007). Culture obtained bacterial isolates still can provide a great deal of information, amending direct-approach environmental studies (Chong et al. 2013). They create the opportunity of deep genetic analysis as well as investigation of physiological traits. In this regard, we investigated the genetic and metabolic characteristics of 43 Polaromonas isolates originating from two Arctic and one Antarctic glacier to assess the variability of this genus on a local and a global scale. We hypothesize that isolates from neighboring glaciers will display similar characteristics, leading to a clear distinction between northern and southern polar region originating strains. To test this hypothesis, we used 16S rRNA gene sequences along with the intergenic transcribed spacers (ITS) to discriminate closely related strains. Phenotypic microarray technology was employed to further diverge the isolates based on their metabolic profiles. Obtained data served to create dendrograms, highlighting the variability within those strains. This approach has not been applied to Polaromonas isolates before, therefore providing valuable data for environmental microbiology.

\section{Materials and methods}

\section{Sites and sampling}

Hans and Werenskiold Glaciers are located on the north shore of the Hornsund Fiord at Spitsbergen Island (Svalbard Archipelago) in Arctic. Hans Glacier, a grounded tidewater glacier has a surface of about $57 \mathrm{~km}^{2}$ and its bottom reaches $100 \mathrm{~m}$ below sea level. Maximum ice thickness was estimated to be $400 \mathrm{~m}$. Werenskiold Glacier is a land-based valley glacier next to Hans Glacier (Grzesiak et al. 2015b). Ecology Glacier is situated at the western shore of Admiralty Bay, on King George Island, South Shetland Archipelago, Antarctica (Grzesiak et al. 2015a).

Ice and cryoconite material were taken from 3 points on the glaciers surface in a transect running up the glacier, from glacial terminus area to the snow line at the top of the ablation zone. The transect on Hans Glacier had a length of 5120 m, on Werenskiold Glacier-3420 m and on Ecology Glacier-1841 m.

Ice from the glacier's surface (approx. $20 \mathrm{~cm}$ ) was crushed with an $70 \%$ ethanol solution sterilized and deionized water-washed Tonar ice auger $(158 \mathrm{~cm}$ long, $130 \mathrm{~mm}$ diameter), collected using sterile plastic spatulas and placed into sterile plastic bags. The crushed ice was gathered from 5 points per sampling site, in an area of $100 \mathrm{~m}^{2}$. Pooled cores totaled $3 \mathrm{~kg}$ per site. Cryoconite holes were drained of water and sediment with a $160 \mathrm{~mL}$ sterile plastic syringe, and the material was transported in $500 \mathrm{~mL}$ sterile bottles to a field laboratory and processed within $2 \mathrm{~h}$. Five cryoconite holes per site were drained and pooled.

\section{Sample preparation and strain isolation}

Ice samples were melt in a refrigerator $\left(4^{\circ} \mathrm{C}\right)$ before processing for microbiological analyses. Cryoconite material was shaken gently on a universal shaker (Premed, model 327) (120 rpm, $20 \mathrm{~min}, 5{ }^{\circ} \mathrm{C}$ ). Suspensions were then returned to the refrigerator for $10-20 \mathrm{~min}$ to allow larger particles to settle. Aliquots of $1,0.5$ and $0.1 \mathrm{~mL}$ were spread-plated on R2A agar plates (Biocorp) and incubated in darkness at $4{ }^{\circ} \mathrm{C}$ for 6 weeks. After 6 weeks of incubation, several colony types that differed in terms of size, color, shape, and other colony characteristics were selected per sample. Pure isolates derived from streaking colonies for isolation were passed through the nonstaining $(\mathrm{KOH})$ test for determination of Gram reaction (Buck 1982). Only those isolates that exhibited the reaction characteristic to Gram-negative bacteria were kept for further investigation. 


\section{Strain DNA isolation, 16S rRNA region and ITS amplification and sequencing}

DNA isolation from bacterial isolates for PCR was carried out using the boiling lysis method. Polaromonas cells were relatively easy to open using this simple method. Single colony was picked from R2A agar plate and suspended in $50 \mu 1$ of sterile MiliQ water. The suspension was boiled in $98^{\circ} \mathrm{C}$ for 2 min and cooled to $8{ }^{\circ} \mathrm{C}$ in thermal cycler following centrifugation for $1 \mathrm{~min}$ in microcentrifuge.

One $\mu \mathrm{L}$ of supernatant was used for PCR. Amplification targeted two regions: (I) 16S rRNA gene, using universal primers $27 \mathrm{~F}$ and $1492 \mathrm{R}$ (Lane 1991) and (II) the internal transcribed spacer (ITS) between 16S rRNA gene and 23S rRNA gene region with use of the primers 1407F, targeting inside the 16S rRNA gene gene and 242R, targeting inside the 23S rRNA gene gene (Lane 1991). Both PCR amplifications were done in the same reaction conditions: 1 min of $95{ }^{\circ} \mathrm{C}$ initial denaturation followed by 30 cycles of $95{ }^{\circ} \mathrm{C}$ for $15 \mathrm{~s}, 55^{\circ} \mathrm{C}$ annealing for $15 \mathrm{~s}$ and elongation $72{ }^{\circ} \mathrm{C}$ for $1 \mathrm{~min}$, using DreamTaq polymerase (Thermo Scientific-Fermentas). Obtained PCR products ( $1500 \mathrm{bp}$ for 16S rRNA gene fragment and $\sim 1100$ bp for ITS fragment) were purified using Exonuclease I/Alkaline phosphatase mix (Thermo Scientific-Fermentas). 16S rRNA gene amplicons were sequenced using internal 16S rRNA gene primers: 341F, 518R and 928F (Weidner et al. 1996) and ITS PCR products were sequenced with PCR primers with use of BigDye Terminator v.3.1 chemistry and ABI3730x1 genetic analyzer at the DNA Sequencing Laboratory (Institute of Biochemistry and Biophysics PAS). Sequencing reads were manually corrected and assembled into contigs using Seqman software (DNAStar).

\section{Microarray metabolic fingerprinting}

The selected strains were cultivated in $\mathrm{R} 2 \mathrm{~A}$ broth on a rotary shaker (WL-972, JWElectronics) for 7 days in $10{ }^{\circ} \mathrm{C}$. After the given incubation time, the cells were harvested by centrifugation in a sterile $2 \mathrm{~mL}$ Eppendorf-type tube (9000 rpm for $3 \mathrm{~min}$ in a MPW-52 microcentrifuge), washed twice and suspended in sterile $0.9 \%$ saline. Bacterial suspensions were added to a vial of GEN III MicroPlate IF C inoculation fluid until transmittance reached $90 \% .100 \mu \mathrm{L}$ aliquots of each suspension were added to each well of Biolog GEN III microplates (Biolog Inc., Hayward, CA, USA). The plates were incubated in darkness at $10{ }^{\circ} \mathrm{C}$, the color development was measured at $590 \mathrm{~nm}$ with a microplate reader (OmniLog) and cellular respiration was measured kinetically by determining the colorimetric reduction of tetrazolium dye. Data were collected approximately three times a week over a 21 day period. The GEN III MicroPlates assesses the ability of a broad range of bacteria to utilize a pallet of different carbohydrates, amino and carboxylic acids, respiration in varying salinity and $\mathrm{pH}$ conditions as well as in the presence of various growth inhibitors (+one control well with no-carbon and one positive control). Absorbance data from the different reading times (given in OmniLog arbitrary units) were first blanked against the time "zero" reading and then the values were blanked against the respective control well containing nocarbon source. Ability to respire in given conditions was scored as positive when it was $\geq 30 \%$ of the respective positive control well value.

\section{Sequence identification, whole genome sequencing and dendrogram construction}

16S rRNA gene fragments and ITS nucleotide sequences were aligned against reference sequence database GenBank (Johnson et al. 2008) using BLAST (Altschul et al. 1990) and using the RDP classifier online program (Cole et al. 2009). Sequences scoring in both databases as Polaromonas $\mathrm{sp}$. were taken for further processing.

The ITS region sequence was used to discriminate closely related strains, in total 43 isolates were typed and submitted for whole genome sequencing using Illumina technology. For this purpose, total DNA was isolated from $50 \mathrm{ml} \mathrm{R} 2$ broth cultures using CTAB/lysozyme method (Wilson 1987). DNA quality was checked on agarose gel and template quantity was estimated using fluorometry by Qubit 2.0 fluorimeter. Illumina shotgun library was constructed using KAPA reagents. Sequencing was done in paired end mode on the MiSeq sequencer using 600 cycle chemistry kit. Obtained sequence reads were trimmed by quality using FastX toolkit and assembled into contigs using Newbler de novo assembler v3.0 (Roche).

Whole genome sequencing data of Polaromonas isolates was used to obtain complete sequence of 16S rRNA gene fragment and ITS regions. Bacterial rRNA gene region was extracted from the assembly dataset based on analysis of Newblers ContigGraph.txt result file. Contigs of the size c.a. $5.6 \mathrm{~kb}$ with 5-6 times higher sequence coverage than the rest of the assembly were taken for analysis. 16S rRNA gene fragment and ITS isolate sequence was aligned to $5.6 \mathrm{~kb}$ sequence region and manually inspected using Seqman (DNAStar) program. As a result, complete nucleotide sequences of these two regions were extracted based on 16S rRNA gene fragment and ITS PCR primers positions. 16S rRNA gene and ITS sequences were deposited in GenBank under accession numbers KU586628-KU586713.

Multiple sequence alignments were performed using ClustalW program. Phylogenetic trees were constructed using MEGA6 software and Neighbour-Joining method. Bootstrap values for phylogenetic comparisons were based on 1000 pseudoreplicates. Isolate designations indicate 
the hemisphere and glacier of origin: $\mathrm{N}-$ Arctic, $\mathrm{S}$-Antarctica, H-Hans Glacier, W-Werenskiold Glacier, EEcology Glacier. 16S and ITS sequences of P. naphthalenivorans strain CJ2 and Polaromonas sp. strain JS666 were used as reference due to the complete gene sequences. Rhodoferax ferrireducens strain T118 sequences were used as outgroups.

Clustering analysis of the Polaromonas strains responses in GEN III microplates was performed using the unweighted pair-group method and the Euclidean distance (UPGMA) for dendrogram construction. Data were analyzed statistically using Statistica version 10 (StatSoft Inc.) and Canoco ver. 4.5 for Windows (Ter Braak and Šmilauer 2002) for the principal component analysis. PCA was conducted using metabolic and sequence-based molecular data. For the latter a percentage of dissimilarity between a given sequence and the respective reference sequence of $R$. ferrireducens was calculated.

\section{Results}

Forty-three Polaromonas isolates were obtained from surface of Arctic and Antarctic glaciers. Nineteen isolates came from Ecology Glacier surface (King George Island, Antarctica), 12 from Hans Glacier and 12 from Werenskiold Glacier (each located at Spitsbergen Island, Arctic). Blastn searches indicate $99 \%$ similarity of the Antarctic strains to Polaromonas vacuolata, whereas Arctic strains showed closest similarity to $P$. naphthalenivorans, $P$. cryoconiti and $P$. glacialis.

The phylogenetic tree based on complete 16S rRNA gene sequences is shown in Fig. 1. Three groups emerged when clustering the sequences. The Ecology Glacier strains form a uniform group, distant from the Arctic isolates, which clustered in two subgroups, comprising roughly the strains from a particular glacier, although with some isolates from the other glacier mixing in. The Antarctic strain E9S clustered loosely with the Arctic strains.

The phylogenetic tree based on internal transcribed spacer (ITS) sequences is shown in Fig. 2. The Antarctic isolates are more differentiated. Two groups emerged within the Ecology Glacier isolated strains, the two major clusters of Arctic isolates remained, with the Antarctic isolate E9S clustering again with the Arctic group.

The percentage of strains displaying positive responses in the GENIII plates is displayed in Table 1 and Table 1S. All examined strains efficiently reduced tetrazolium violet

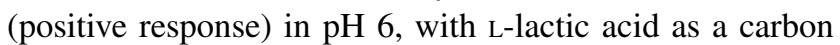
source and in the presence of $1 \%$ sodium lactate. Other frequently utilized carbon sources were: glycerol, L-alanine, L-aspartic acid, L-glutamic acid, D,L-malic acid and $\beta$-hydroxy-D,L-butyric acid. Major differences between the isolates from particular glaciers have emerged when examining responses at $\mathrm{pH} 5, \alpha$-D-glucose, D-galacturonic acid, L-galactonic acid lactone, D-gluconic acid, $\gamma$-amino-butyric acid and acetic acid. $11 \%$ of Antarctic strains respired in pH5, whereas over $50 \%$ of Arctic strains gave a positive response at this $\mathrm{pH}$ level. Carbohydrates were on average weakly assimilated, with the exception of $\alpha$-D-glucose which was utilized by $47 \%$ of the Ecology Glacier strains, but none of the Arctic glacier strains. Gluconic acid was assimilated by the majority of the Arctic strains and none on the Antarctic strains. Acetic acid utilization has been confirmed in a great majority of the Hans and Werenskiold Glaciers strains, yet only in $26 \%$ of the Ecology Glacier strains.

The tree based on metabolic traits of the strains obtained by means of GenIII Biolog Plates is shown in Fig. 3. Three distinct groups have emerged, similarly as in the phylogenetic tree based on complete 16S rRNA gene sequences. Within the Antarctic isolate group, two subgroups have formed similarly as in the ITS tree, although with some exceptions as indicated by the circled numerals.

The average positive response numbers did not differ much between the Glaciers, with Ecology Glacier displaying 19.9 positive responses, Hans Glacier isolates 21.2 and Werenskiold Glacier isolates 25.5 (Fig. 4). Yet, the difference between Ecology and Werenskiold Glacier isolates response numbers was statistically significant $(p<0.05)$.

The principal component analysis clustered the Polaromonas strains in 3 groups, according to the glaciers which they were isolated from, with intermixing of single strains. Characteristics like 16S rRNA gene sequences, assimilation of acetate, gluconate and glucose differentiated the Arctic from the Antarctic strains. ITS sequences, ability to oxidize glycerol, D-galacturonic acid and $\gamma$-amino-butyric acid differentiated arctic isolates into 2 groups (Fig. 5).

\section{Discussion}

Members of the Polaromonas genus were isolated from a variety of habitats, were reported via direct diversity assessment methods from various ecosystems and were considered as a marker when investigating polar, marine and freshwater environments (Willems 2014). In this study, we present the genetic and metabolic variability within Polaromonas isolates obtained from supraglacial habitats, such as surface ice and cryoconite hole sediment from two Arctic and one Antarctic glacier.

\section{Biogeography, selection and adaptation}

Phylogenetic clustering of 16S rRNA gene sequences of investigated Polaromonas spp. differentiated them into 2 


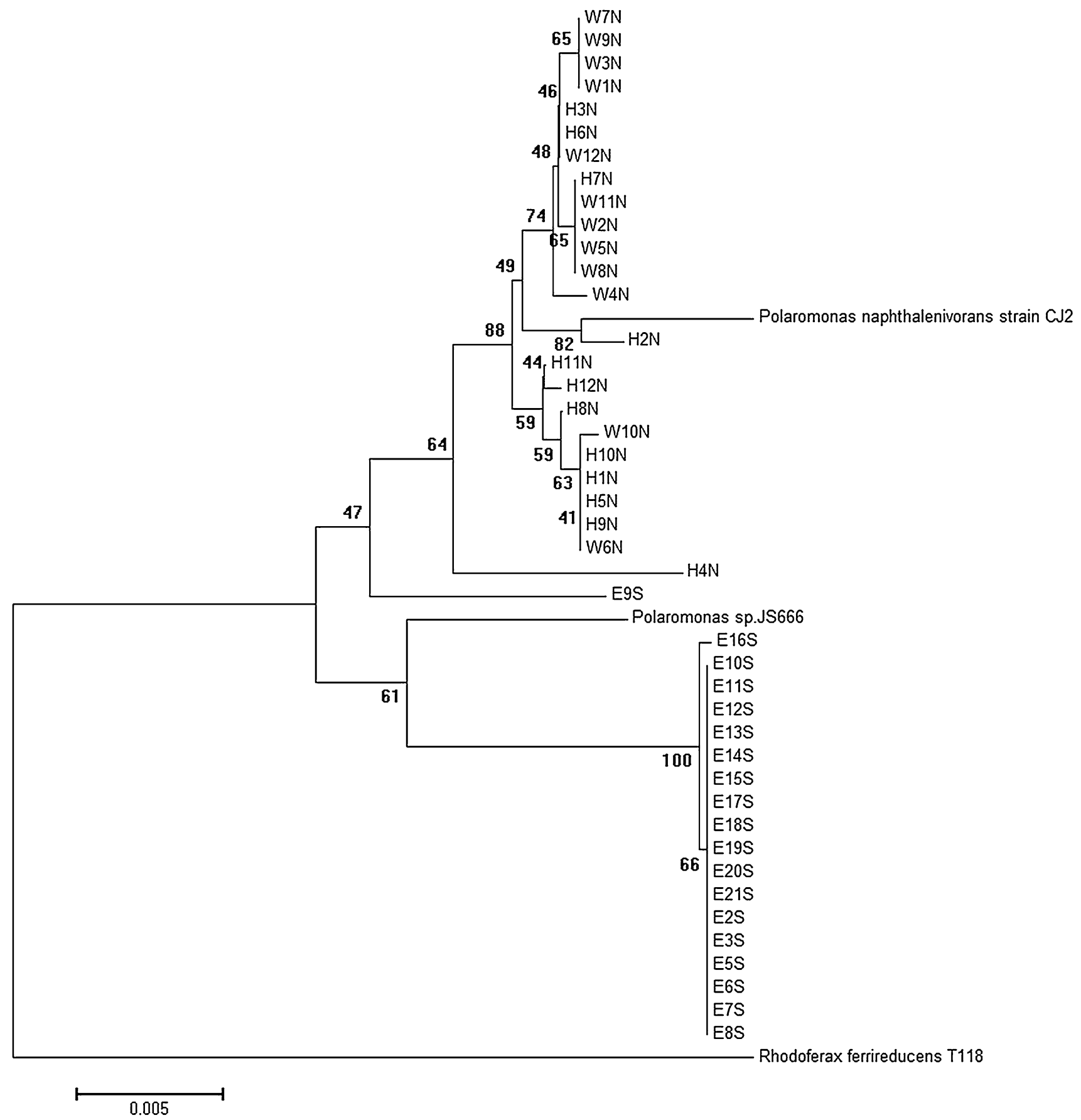

Fig. 1 Phylogenetic tree constructed using complete 16S rRNA gene sequences of Polaromonas isolates. Isolate designations indicate the hemisphere and glacier of origin ( $N$ Arctic, $S$ Antarctica, $H$ Hans Glacier, $W$ Werenskiold Glacier, $E$ Ecology Glacier). The tree was built

distinct groups-the Arctic and the Antarctic. 16S rRNA gene sequence difference between those two clades was $2.7 \%$ on average, which designates the Antarctic and the Arctic isolates as different species (Jogler et al. 2011). A similar situation was observed by Cameron et al. (2012), when examining bacterial communities in cryoconite holes with the neighbor-joining method. Bootstrap values are indicated at the nodes. $R$. ferrireducens strain T118 sequence has been used as an outgroup

of Arctic and Antarctic glaciers by means of T-RFLP. Dispersal of psychrophilic bacteria between poles was discussed before (Staley and Gosink 1999). Migrating birds, cold, deep sea currents and upper atmosphere air masses were taken into consideration as possible transport agents of polar microbiota. They were all dismissed due to 


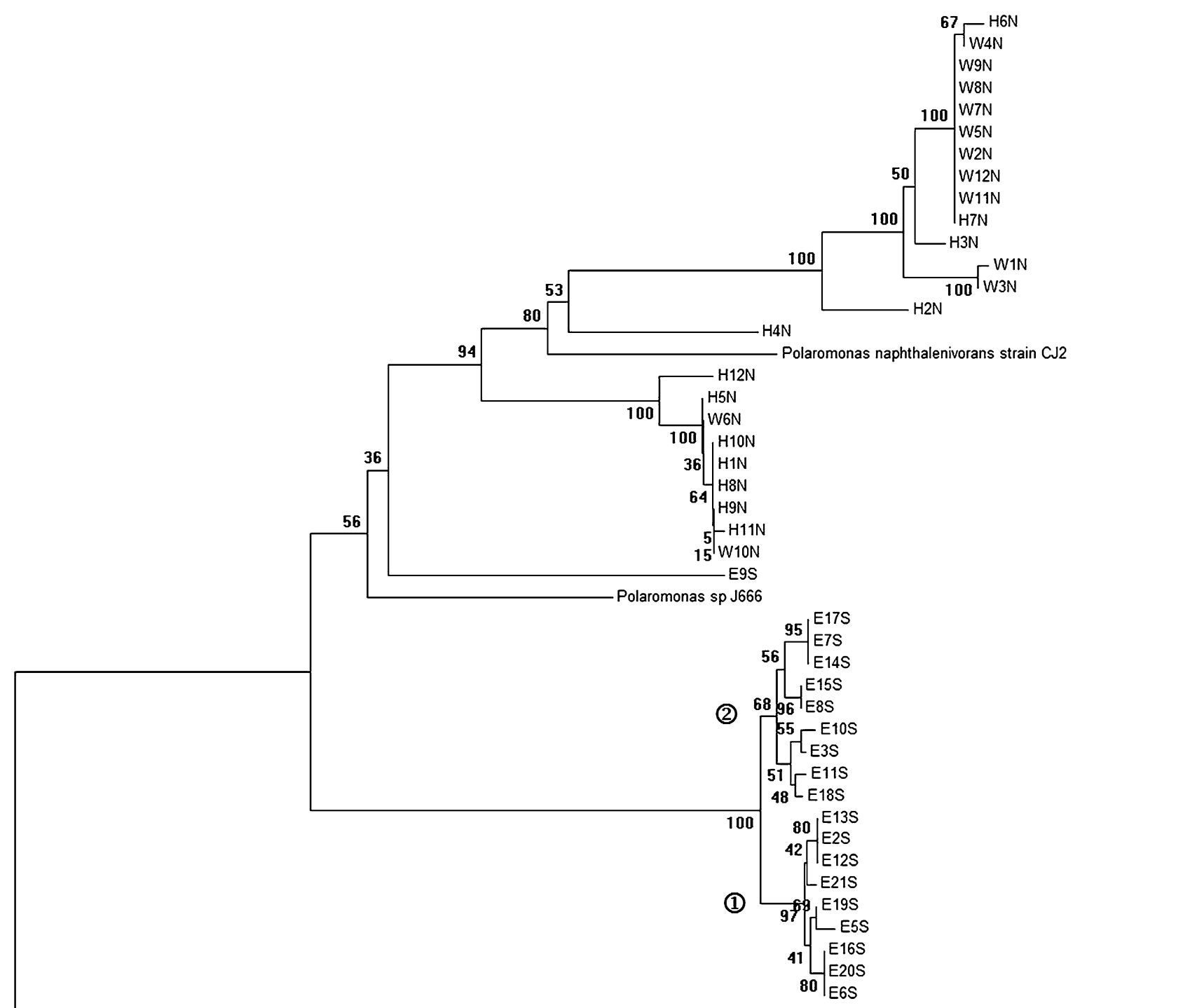

Rhodoferax ferrireducens $\mathrm{T} 118$

0.02

Fig. 2 Phylogenetic tree constructed using complete ITS sequences of Polaromonas isolates. Isolate designations indicate the hemisphere and glacier of origin ( $N$ Arctic, $S$ Antarctica, $H$ Hans Glacier, $W$ Werenskiold Glacier, $E$ Ecology Glacier). The tree was built with

high-temperature amplitudes, slow rate or simply because of lack of evidence for their occurrence. However, Sattler et al. (2001) showed in following years, that bacterial cells can survive and even reproduce in supercooled cloud droplets at high altitudes. In this respect, Polaromonas sp. DNA sequences were recovered from air sampled at Fløyen Mountain, Norway (Fahlgren et al. 2010). Whether those cells are capable of withstanding a journey from one pole to another remains unclear.

The Arctic cluster was separated into two groups, each of them containing a majority of isolates from one glacier clustered together with a few isolates from the neighboring the neighbour-joining method. Bootstrap values are indicated at the nodes. R. ferrireducens strain T118 sequence has been used as outgroups. (1) ITS Ecology Glacier group 1; (2) ITS Ecology Glacier group 2

glacier. Such "overlapping” of bacterial sequences was also recognized when analyzing community structures of 3 adjacent Svalbard glaciers (Edwards et al. 2013). The composition of the two groups, emerging on the 16S rRNA gene tree within the Arctic clade, remained the same on the ITS tree. Furthermore, the groups were maintained when constructing the tree based on phenotypic traits. This implies that isolates within those two groups diverged genetically and metabolically from one another a considerable time in the past. Whether the dominance of one group on a glacier is due to selection pressure or simply by the proximity of the glacier to the groups primary reservoir remains unclear. 
Table 1 Percentage of positive responses of Polaromonas isolates in selected wells showing differences and similarities between glaciers

\begin{tabular}{|c|c|c|c|c|c|c|c|}
\hline \multirow[t]{2}{*}{ Metabolic trait } & \multicolumn{3}{|c|}{ Glacier } & \multirow[t]{2}{*}{ Metabolic trait } & \multicolumn{3}{|c|}{ Glacier } \\
\hline & $\mathrm{E}$ & $\mathrm{H}$ & W & & E & $\mathrm{H}$ & $\mathrm{W}$ \\
\hline ph6 & 100 & 100 & 100 & Vancomycin & 58 & 67 & 67 \\
\hline ph5 & 11 & 50 & 75 & Tetrazolium violet & 11 & 0 & 0 \\
\hline $1 \% \mathrm{NaCl}$ & 100 & 92 & 100 & Tetrazolium blue & 5 & 58 & 33 \\
\hline$\alpha$-D-Glucose & 47 & 0 & 0 & p-Hydroxy-phenylacetic acid & 0 & 17 & 8 \\
\hline D-Fucose & 5 & 0 & 0 & Methyl pyruvate & 42 & 42 & 75 \\
\hline $1 \%$ sodium lactate & 100 & 100 & 100 & L-Lactic acid & 100 & 100 & 100 \\
\hline D-Mannitol & 32 & 0 & 0 & $\alpha$-Keto-glutaric acid & 42 & 42 & 67 \\
\hline D-Arabitol & 32 & 0 & 0 & D-Malic acid & 74 & 42 & 100 \\
\hline Glycerol & 63 & 25 & 83 & L-Malic acid & 68 & 92 & 100 \\
\hline Rifamycin SV & 95 & 100 & 100 & Bromo-succinic acid & 37 & 25 & 75 \\
\hline L-Alanine & 84 & 67 & 92 & Lithium chloride & 11 & 0 & 0 \\
\hline L-Aspartic acid & 95 & 100 & 100 & Tween 40 & 37 & 75 & 42 \\
\hline L-Glutamic acid & 89 & 92 & 100 & $\gamma$-Amino-butyric acid & 5 & 42 & 83 \\
\hline L-Pyroglutamic acid & 37 & 8 & 0 & $\alpha$-Hydroxy-butyric acid & 42 & 33 & 58 \\
\hline Lincomycin & 100 & 67 & 100 & $\beta$-Hydroxy-D, L-Butyric acid & 89 & 100 & 100 \\
\hline D-Galacturonic acid & 5 & 33 & 83 & $\alpha$-Keto-butyric acid & 32 & 25 & 8 \\
\hline L-Galactonic acid lactone & 5 & 8 & 75 & Acetoacetic acid & 47 & 67 & 17 \\
\hline D-Gluconic acid & 0 & 67 & 100 & Propionic acid & 11 & 17 & 50 \\
\hline D-Glucuronic acid & 26 & 33 & 58 & Acetic acid & 26 & 100 & 92 \\
\hline Quinic acid & 5 & 17 & 0 & Aztreonam & 63 & 50 & 42 \\
\hline D-Saccharic acid & 0 & 8 & 33 & Sodium butyrate & 0 & 33 & 25 \\
\hline
\end{tabular}

$H$ Hans Glacier, $W$ Werenskiold Glacier, $E$ Ecology Glacier
However, profound differences in physico-chemical values of glacial surfaces not only between two hemispheres but also within one region were reported previously (Anesio et al. 2009; Grzesiak et al. 2015b; Cameron et al. 2012), which implies, that selection forces are of different quality on each glacier. Xiang et al. (2009) postulated that the shape of microbial communities on glacier is caused by the selection of deposited microbial cells. Investigations on the Ecology Glacier (Grzesiak et al. 2015a) and on the Werenskiold and Hans glaciers (Grzesiak et al. 2015b) regarding physico-chemical controls of microbial supraglacial communities may shed some light on the Polaromonas isolates' metabolic traits as adaptations to conditions on a particular glacier. Most of the Polaromonas strains from Arctic glaciers were active in $\mathrm{pH} 5$, whereas only $11 \%$ of the Antarctic strains could respire in such conditions. This could be explained by the $\mathrm{pH}$ of the glacier surface, where ice and cryoconites of Hans and Werenskiold Glaciers had a pH ranging from 3.34 to 4.77 (Grzesiak et al. 2015b), the Ecology Glacier surface displayed $\mathrm{pH}$ in the range of 6.10-7.15 (Grzesiak et al. 2015a). The lack of activity of investigated Polaromonas cells at salt concentrations $4 \%$ and above can also be explained by supraglacial conditions. Dissolved salts amounts in Ecology Glacier cryoconite hole water were minimal, as indicated by its low conductivity, not exceeding $3.4 \mu \mathrm{S} \mathrm{cm}^{-1}$ (Mieczan et al. 2013). Polaromonas vacuolata, isolated from Antarctic sea ice, is the only halophile within this genus described to date, although its salinity range of growth is quite high (0-6\%) (Irgens et al. 1996). Considering marine aerosol dispersal by high velocity Antarctic winds (Pearce et al. 2009), supraglacial strains obtained in this study, closely related to $P$. vacuolata may be of sea origin.

High affinity of investigated Polaromonas strains for simple organic acids, hints an abundance of those carbon compounds in the supraglacial environment. Sources of those acids may be diverse, allochtonic, as well as autochtonic (Stibal et al. 2008). It has been proven on several occasions that in many aquatic environments organic acids are a result of photodegradation of recalcitrant substances, like humic and fulvic acids (Wetzel et al. 1995; Watanabe et al. 2009). They can also be produced on the glacier surface via microbes, leaching from live cells during stress conditions (Medina-Sánchez and Villar-Argaiz 2006) or being actively released to solubilize phosphate and other biogenic elements (Rodríguez and Fraga 1999). Scavenging of those small molecules may give the Polaromonas an advantage in those oligotrophic conditions. 


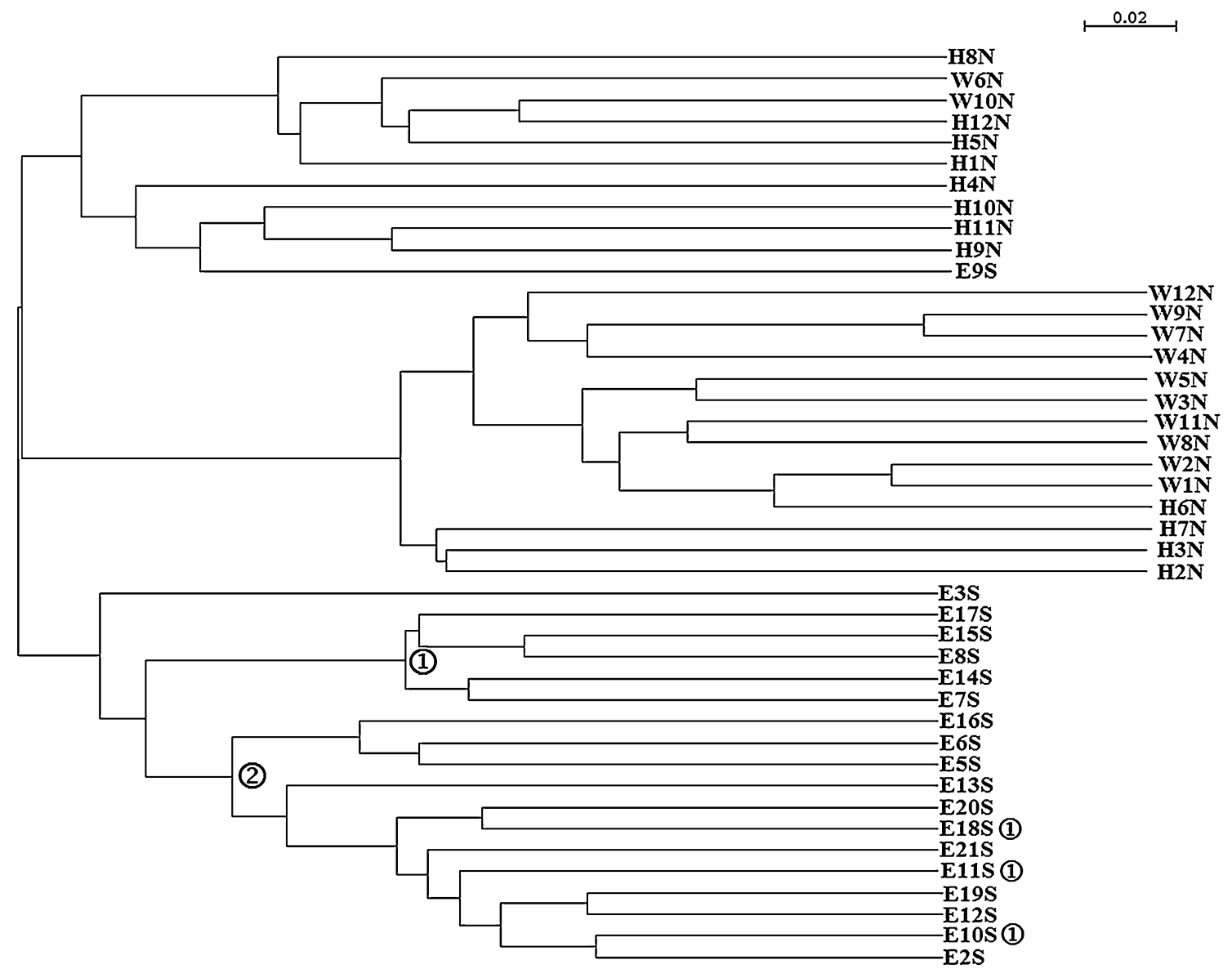

Fig. 3 Dendrogram constructed using data obtained from GENIII microplate metabolic features of Polaromonas isolates. Isolate designations indicate the hemisphere and glacier of origin ( $N$ Arctic, $S$ Ant-

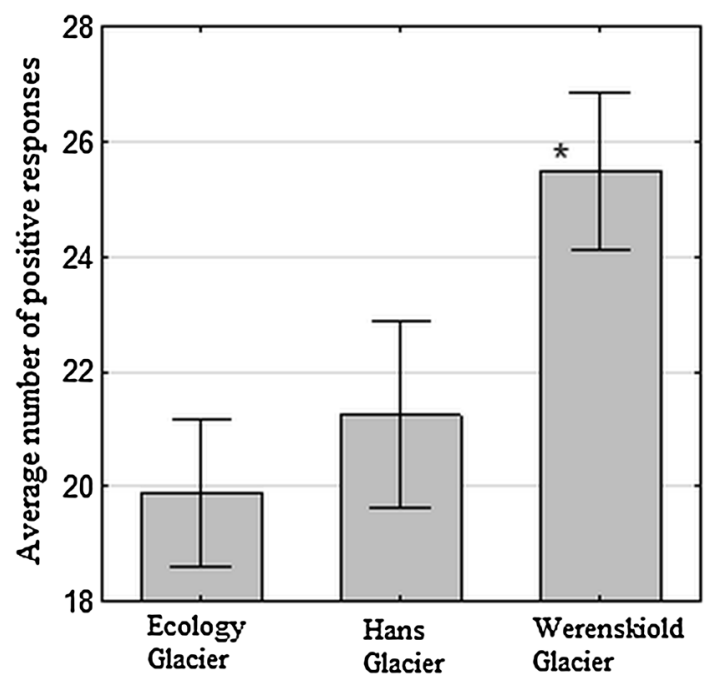

Fig. 4 Number of positive reactions in GENIII microplates of Polaromonas isolates from a particular glacier. Asterisk indicates a statistical significance of $p<0.05$ arctica, $H$ Hans Glacier, $W$ Werenskiold Glacier, $E$ Ecology Glacier). (1) ITS Ecology Glacier group 1; (2) ITS Ecology Glacier group 2

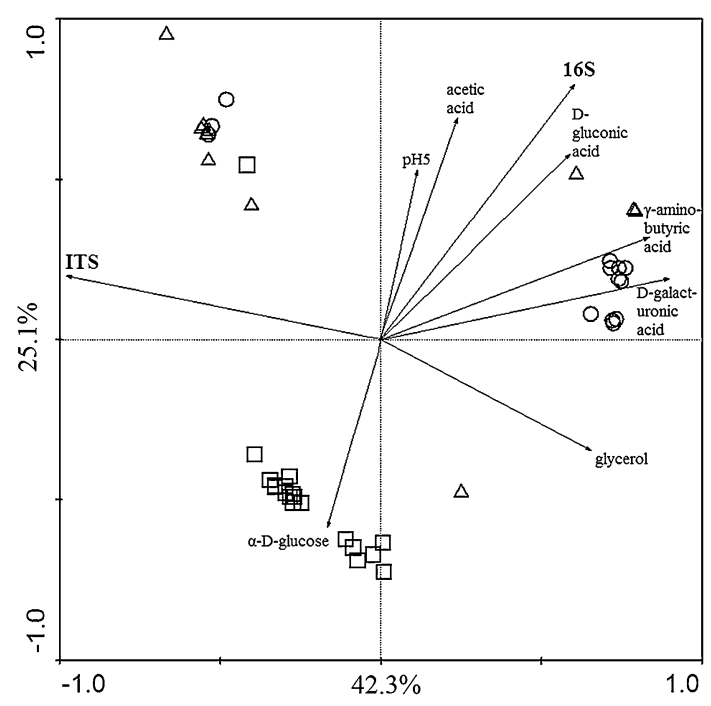

Fig. 5 Principal component analysis clustering of isolates based on $16 \mathrm{~S}$ rRNA gene, ITS sequences and metabolic fingerprinting. Square Ecology Glacier isolates, Triangle Hans Glacier isolates, Circle Werenskiold Glacier isolates 
Fig. 6 Microphotograph of algae and bacteria agglomerate from Ecology Glacier surface: a DAPI stained bacterial cells (black arrow) imbedded in extracellular matrix of a round algae cell (under UV light). b Autofluorescence of the same algae cell under green-light excitation
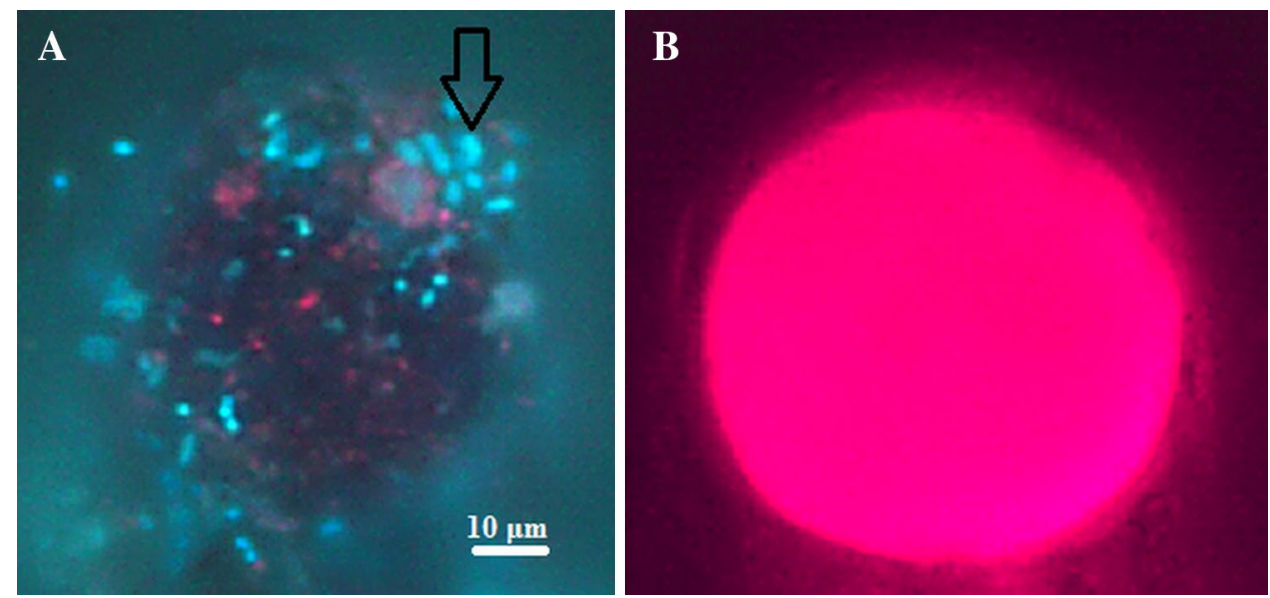

\section{Microevolution, phenotype and niche separation}

The isolates comprising the Antarctic branch of the 16S rRNA gene tree were separated into two branches on the ITS tree. As the ITS sequences evolve more quickly than the 16S rRNA gene sequences it is safe to assume that the divergence within this group has occurred fairly recently, perhaps even on the glacier itself, following deposition and selection. Some isolates still share properties not present in their closest genetic relatives. This could further support the recent divergence of those two groups. Differences in ITS sequences and phenotypes among bacteria sharing the same 16S rRNA gene sequence were observed before (Jaspers and Overmann 2004; Brown et al. 2005) and were repeatedly linked to niche separation (Brown and Fuhrman 2005; Hahn and Pöckl 2005; Jogler et al. 2011). Those authors pointed spatial, temporal, temperature and dissolved organic carbon quality-dependent ecological niche differentiation. Spatio-temporal causes seem not to apply to the diversification observed in this study, as the sampling on the Ecology Glacier surface was undertaken within a few hours and the clusters contain isolates from several sampling points. Chemical composition within the particular site or even biological interactions might be therefore responsible. Several features of the Antarctic Polaromonas strains points towards host-symbiont interactions as possible drivers of such diversification. Nearly half of the strains from Ecology Glacier surface exhibited D-glucose utilization capability, but none of those strains respired when gluconic acid was the only carbon source, which was readily consumed by Arctic strains. In the heavily solar radiation impacted glacial surfaces (Säwström et al. 2002) glucose may easily be oxidized inter alia to gluconic acid (Phillips and Rickards 1969). The phenomenon that the Antarctic strains utilize glucose yet lack the ability to degrade more complex carbohydrates like dextrin may suggest that they tightly adhere to algae cells, which secrete simple carbohydrates in stress conditions that are immediately consumed by bacteria, before being oxidized. Microscope observations of aggregates containing algae and bacteria were confirmed from Ecology Glacier surface (Fig. 6). Such hostsymbiont interaction may explain the separation within the Ecology Glacier isolates, where the niche separations occur in accordance with host specificity. Such phenomenon has been observed by Šimek et al. (2011), where Limnohabitans sp. strains were proposed to respond to different extracellular algae-derived substances by niche separation. Antarctic Polaromonas strains also have on average lower assimilation capabilities than Arctic strains. Loss of function in symbionts were connected with growing dependency to host metabolites (Ochman and Moran 2001). Furthermore, Polaromonas-like bacterium has been found in a consortium with a phototrophic partner (Kanzler et al. 2005), suggesting that within this genus, symbiotic interaction might be common.

In conclusion, the presented data amend the information on Polaromonas spp. biogeography, evolution and physiology. Members of the genus Polaromonas occupy supraglacial habitats of Arctic and Antarctic glaciers. Darcy et al. (2011) postulate a global dispersal of most Polaromonas phylotypes. Distribution by air currents is likely the way of propagating the cells of this genus, but the efficiency of seeding a glacial surface with cells that were transported across great distances and from a variety of different environments might be greater on local than global scales. Selection mechanisms caused by prevailing environmental conditions on a glacier may drastically reduce the deposited diversity. Furthermore, biotic and abiotic factors may drive postselectional niche separation and microevolution within the Polaromonas genus.

Acknowledgments This work was supported by the National Science Center, Poland (Grant N N304 106940). 
Open Access This article is distributed under the terms of the Creative Commons Attribution 4.0 International License (http://creativecommons.org/licenses/by/4.0/), which permits unrestricted use, distribution, and reproduction in any medium, provided you give appropriate credit to the original author(s) and the source, provide a link to the Creative Commons license, and indicate if changes were made.

\section{References}

Altschul SF, Gish W, Miller W, Myers EW, Lipman DJ (1990) Basic local alignment search tool. J Mol Biol 215(3):403-410

Anesio AM, Hodson AJ, Fritz A, Psenner R, Sattler B (2009) High microbial activity on glaciers: importance to the global carbon cycle. Glob Change Biol 15:955-960

Brown MV, Fuhrman JA (2005) Marine bacterial microdiversity as revealed by internal transcribed spacer analysis. Aquat Microb Ecol 41:15-23

Brown MV, Schwalbach MS, Hewson I, Fuhrman JA (2005) Coupling 16S-ITS rRNA gene clone libraries and automated ribosomal intergenic spacer analysis to show marine microbial diversity: development and application to a time series. Environ Microbiol 7(9):1466-1479

Buck JD (1982) Nonstaining (KOH) method for the determination of Gram reactions of marine bacteria. Appl Environ Microb 44:992-993

Cameron KA, Hodson AJ, Osborn AM (2012) Structure and diversity of bacterial, eukaryotic and archaeal communities in glacial cryoconite holes from the Arctic and the Antarctic. FEMS Microbiol Ecol 82:254-267

Chong CW, Goh YS, Convey P, Pearce D, Tan IKP (2013) Spatial pattern in Antarctica: what can we learn from Antarctic bacterial isolates? Extremophiles 17:733-745

Cole JR, Wang Q, Cardenas E, Fish J, Chai B, Farris RJ, Kulam-SyedMohideen AS, McGarrell DM, Marsh T, Garrity GM, Tiedje JM (2009) The ribosomal database project: improved alignments and new tools for rRNA analysis. Nucleic Acids Res 37:D141-D145

Darcy JL, Lynch RC, King AJ, Robeson MS, Schmidt SK (2011) Global distribution of Polaromonas phylotypes-evidence for a highly successful dispersal capacity. PLoS One 6(8):e23742

Edwards A, Rassner SME, Anesio AM, Worgan HJ, Irvine-Fynn TDL, Williams HW, Sattler B, Griffith GW (2013) Contrasts between the cryoconite and ice-marginal bacterial communities of Svalbard glaciers. Polar Res 32:19468

Fahlgren C, Bratbak G, Sandaa R-A, Thyrhaug R, Zweifel U (2010) Diversity of airborne bacteria in samples collected using different devices for aerosol collection. Aerobiologia 104:285-295

Grzesiak J, Zdanowski MK, Górniak D, Świątecki A, Aleksandrzak-Piekarczyk T, Szatraj K, Sasin-Kurowska J, Nieckarz M (2015a) Microbial community changes along the Ecology Glacier ablation zone (King George Island, Antarctica). Polar Biol 38:2069-2083

Grzesiak J, Górniak D, Świątecki A, Aleksandrzak-Piekarczyk T, Szatraj K, Zdanowski MK (2015b) Microbial community development on the surface of Hans and Werenskiold Glaciers (Svalbard, Arctic): a comparison. Extremophiles 19:885-897

Hahn MW, Pöckl M (2005) Ecotypes of planktonic Actinobacteria with identical 16S rRNA genes adapted to thermal niches in temperate, subtropical, and tropical freshwater habitats. Appl Environ Microb 71(2):766-773

Hodson A, Anesio AM, Tranter M, Fountain A, Osborn M, Priscu J, Laybourn-Parry J, Sattler B (2008) Glacial ecosystems. Ecol Monogr 78:41-67
Hubbell SP (2001) The unified neutral theory of biodiversity and biogeography. Princeton University Press, Princeton

Irgens RL, Gosink JJ, Staley JT (1996) Polaromonas vacuolata gen. nov., sp. nov., a psychrophilic, marine, gas vacuolated bacterium from Antarctica. Int J Syst Bacteriol 46:822-826

Jaspers E, Overmann J (2004) Ecological significance of microdiversity: identical $16 \mathrm{~S}$ rRNA gene sequences can be found in bacteria with highly divergent genomes and ecophysiologies. Appl Environ Microb 70(8):4831-4839

Jogler M, Siemens H, Chen H, Bunk B, Sikorski J, Overmann J (2011) Identification and targeted cultivation of abundant novel freshwater sphingomonads and analysis of their population substructure. Appl Environ Microb 77(20):7355-7364

Johnson M, Zaretskaya I, Raytselis Y, Merezhuk Y, McGinnis S, Madden TL (2008) NCBI BLAST: a better web interface. Nucleic Acids Res 36:W5-W9

Kanzler BEM, Pfannes KR, Vogl K, Overmann J (2005) Molecular characterization of the nonphotosynthetic partner bacterium in the consortium "Chlorochromatium aggregatum". App Environl Microb 71(11):7434-7441

Lane DJ (1991) 16S/23S rRNA sequencing. In: Stackebrandt E, Goodfellow M (eds) Nucleic acid techniques in bacterial systematics. Wiley, Chichester, pp 115-165

Martiny JBH, Bohannan BJM, Brown JH, Colwell RK, Fuhrman JA, Green JL, Horner-Devine MC, Kane M, Krumins JA, Kuske CR, Morin PJ, Naeem S, Øvreås L, Reysenbach AL, Smith VH, Staley JT (2006) Microbial biogeography: putting microorganisms on the map. Nat Rev Microbiol 4(2):102-112

Medina-Sánchez JM, Villar-Argaiz M (2006) Solar radiation-nutrient interaction enhances the resource and predation algal control on bacterioplankton: a short-term experimental study. Limnol Oceanogr 51:913-924

Mieczan T, Górniak D, Świątecki A, Zdanowski M, Tarkowska-Kukuryk M, Adamczuk M (2013) Vertical microzonation of ciliates in cryoconite holes in Ecology Glacier, King George Island. Pol Polar Res 34(2):201-212

Nemergut DR, Costello EK, Hamady M, Lozupone C, Jiang L, Schmidt SK, Fierer N, Townsend AR, Cleveland CC, Stanish L, Knight R (2011) Global patterns in the biogeography of bacterial taxa. Environ Microbiol 13:135-144

Nielsen KM, Johnsen PJ, Bensasson D, Daffonchio D (2007) Release and persistence of extracellular DNA in the environment. Environ Biosafety Res 6:37-53

Ochman H, Moran NA (2001) Genes lost and genes found: evolution of bacterial pathogenesis and symbiosis. Science 292:1096-1098

Paterson WSB (1994) The physics of glaciers, 3rd edn. Pergamon, Oxford

Pearce DA, Bridge PD, Hughes KA, Sattler B, Psenner R, Russell NJ (2009) Microorganisms in the atmosphere over Antarctica. FEMS Microbiol Ecol 69:143-157

Phillips GO, Rickards T (1969) Photodegradation of carbohydrates. Part IV. Direct photolysis of D-glucose in aqueous solution. J Chem Soc B 0:455-461

Ramette A, Tiedje JM (2007) Biogeography: an emerging cornerstone for understanding prokaryotic diversity, ecology, and evolution. Microb Ecol 53:197-207

Rodrigues DF, Jesus EC, Ayala-del-Rio HL, Pellizari VH, Gilichinsky D, Sepulveda-Torres L, Tiedje JM (2009) Biogeography of two cold-adapted genera: Psychrobacter and Exiguobacterium. ISME J 3:658-665

Rodríguez H, Fraga R (1999) Phosphate solubilizing bacteria and their role in plant growth promotion. Biotech Adv 17:319-339

Sattler B, Puxbaum H, Psenner R (2001) Bacterial growth in supercooled cloud droplets. Geophys Res Lett 28:239-242

Säwström C, Mumford P, Marshall W, Hodson A, Laybourn-Parry J (2002) The microbial communities and primary productivity of 
cryoconite holes in an Arctic glacier (Svalbard $\left.79^{\circ} \mathrm{N}\right)$. Polar Biol 25:591-596

Shiklomanov I (1993) World freshwater resources. In: Gleick PH (ed) Water in crisis: a guide to the world's fresh water resources. Oxford University Press, New York

Šimek K, Kasalický V, Zapomělová E, Horňák K (2011) Alga-derived substrates select for distinct betaproteobacterial lineages and contribute to niche separation in Limnohabitans strains. Appl Environ Microb 77(20):7307-7315

Staley JT, Gosink JJ (1999) Poles apart: biodiversity and biogeography of sea ice bacteria. Annu Rev Microbiol 53:189-215

Stibal M, Tranter M, Benning LG, Rěhák J (2008) Microbial primary production on an Arctic glacier is insignificant in comparison with allochthonous organic carbon input. Environ Microbiol 10:2172-2178

Ter Braak CJF, Šmilauer P (2002) CANOCO reference manual and CanoDraw for Windows user's guide: software for canonical community ordination (version 4.5). Microcomputer Power, Ithaca

Watanabe K, Komatsu N, Ishii Y, Negishi M (2009) Effective isolation of bacterioplankton genus Polynucleobacter from freshwater environments grown on photochemically degraded dissolved organic matter. FEMS Microbiol Ecol 67:57-68
Weidner S, Arnold W, Pühler A (1996) Diversity of uncultured microorganisms associated with the seagrass Halophila stipulacea estimated by restriction fragment length polymorphism analysis of PCR-amplified 16S rRNA genes. Appl Env Microbiol 62(3):766-771

Wetzel RG, Hatcher PG, Bianchi TS (1995) Natural photolysis by ultraviolet irradiance of recalcitrant dissolved organic matter to simple substrates for rapid bacterial metabolism. Limnol Oceanogr 40(8):1369-1380

Willems A (2014) The family Comamonadaceae. In: Rosenberg E et al (eds) The prokaryotes: alphaproteobacteria and betaproteobacteria. Springer, Berlin, pp 777-843

Wilson K (1987) Preparation of genomic DNA from bacteria. In: Ausubel FM, Bent R, Kingston RE et al (eds) Current protocols in molecular biology. Wiley, New York, pp 2.10-2.12

Xiang SR, Shang TC, Chen Y, Yao TD (2009) Deposition and postdeposition mechanisms as possible drivers of microbial population variability in glacier ice. FEMS Microbiol Ecol 70:165-176 